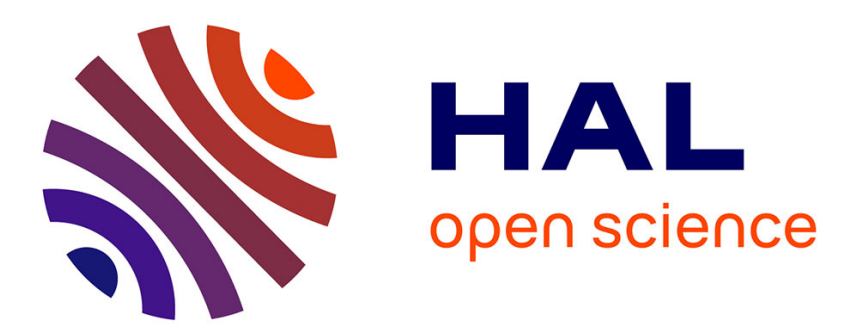

\title{
Luminescence and reflectance studies of the exciton structures in CdTe
}

\author{
P. Simmonds, S. Suga, P. Hiesinger
}

\section{To cite this version:}

P. Simmonds, S. Suga, P. Hiesinger. Luminescence and reflectance studies of the exciton structures in CdTe. Revue de Physique Appliquée, 1977, 12 (2), pp.266-266. 10.1051/rphysap:01977001202026601 . jpa-00244156

\section{HAL Id: jpa-00244156 https://hal.science/jpa-00244156}

Submitted on 1 Jan 1977

HAL is a multi-disciplinary open access archive for the deposit and dissemination of scientific research documents, whether they are published or not. The documents may come from teaching and research institutions in France or abroad, or from public or private research centers.
L'archive ouverte pluridisciplinaire HAL, est destinée au dépôt et à la diffusion de documents scientifiques de niveau recherche, publiés ou non, émanant des établissements d'enseignement et de recherche français ou étrangers, des laboratoires publics ou privés. 


\title{
LUMINESCENCE AND REFLECTANCE STUDIES OF THE EXCITON STRUCTURES IN CdTe
}

\author{
P. SIMMONDS, S. SUGA and P. HIESINGER (*) \\ MPI f. Festkörperforschung, Stuttgart, Germany
}

\begin{abstract}
Résumé. - On étudie la structure interne de la luminescence et de la réflectance due aux excitons liés ou libres dans le tellurure de cadmium de type $n$ et $p$ par des mesures d'effet Zeeman, l'application d'une tension uniaxiale, l'orientation de spin optique et des évaluations de durée de vie. La coupure du doublet sous l'action d'une pression est toujours observée en présence d'excitons liés, elle n'apparaît pas dans le cas d'excitons libres. Ce comportement différent et la polarisation des différentes contributions des excitons liés est comparé aux spectres Zeeman afin d'interpréter l'origine des raies de luminescence. Une comparaison de l'orientation de spin et des durées de vie est effectuée pour toutes les raies excitoniques. Pour un exciton libre, sa dépendance en énergie est discutée en terme de polariton.
\end{abstract}

\begin{abstract}
The internal structure of free and bound exciton luminescence and reflectance in $\mathrm{n}$ and p-type CdTe is investigated through the Zeeman effect, application of uniaxial stress, optical spin orientation and lifetime studies. The doublet stress splitting observed in each component of the bound excitons is contrasted with that of the free exciton. The different stress splitting and polarization of various components of the bound excitons is compared with that of the Zeeman pattern in order to interpret the origin of the luminescence lines. A comparison of the spin orientation and lifetimes between all exciton lines is made. For the free exciton, its energy dependence is discussed on the polariton model.
\end{abstract}

$\left(^{*}\right)$ Present address : Inst. Angew. Festkörperphysik, Freiburg i. Br. 